\title{
Pathogenesis of idiopathic pulmonary fibrosis: review of recent findings Elisabetta Renzoni ${ }^{1 *}$, Veeraraghavan Srihari ${ }^{2}$ and Piersante Sestini ${ }^{3}$
}

\author{
Addresses: ${ }^{1}$ Interstitial Lung Disease Unit, Royal Brompton Hospital and National Heart and Lung Institute, Imperial College London, Emmanuel \\ Kaye Building, 1B Manresa Road, London SW3 6LR, UK; ${ }^{2}$ Department of Medicine, Division of Pulmonary, Allergy and Critical Care, Emory \\ University, 1365 Clifton Rd NE Rm A 4319, Atlanta, GA 30322, USA; ${ }^{3}$ Respiratory Medicine Department, Ospedale "Le Scotte", University of Siena, \\ viale Bracci, 53100 Siena, Italy \\ *Corresponding author: Elisabetta Renzoni (e.renzoni@imperial.ac.uk) \\ FI000Prime Reports 2014, 6:69 (doi:10.12703/P6-69) \\ All FI000Prime Reports articles are distributed under the terms of the Creative Commons Attribution-Non Commercial License \\ (http://creativecommons.org/licenses/by-nc/3.0/legalcode), which permits non-commercial use, distribution, and reproduction in any medium, \\ provided the original work is properly cited. \\ The electronic version of this article is the complete one and can be found at: http://fl000.com/prime/reports/m/6/69
}

\begin{abstract}
Idiopathic pulmonary fibrosis (IPF) is likely to result from the interaction between environmental exposures, including cigarette smoke, and genetic predisposition. This review focuses on clues provided by recent genetic association studies and other selected data and hypotheses. In IPF, association with surfactant mutations has highlighted the importance of type II epithelial cells, while shortened telomeres in some patients suggest that accelerated aging may play a role in the pathogenesis of lung fibrosis, possibly by affecting the renewal/differentiation potential of epithelial cells. The finding that a common variant in mucin 5B predisposes individuals to both familial and sporadic IPF suggests a hitherto under-investigated role of bronchiolar cells and mucins. Although the pathogenetic link between mucins and lung fibrosis is not known, it is possible that MUC5B overexpression interferes with physiological mucosal host defense, with reduced clearance of micro-organisms or inorganic noxious agents, or induction of endoplasmic reticulum stress. Other components of innate and adaptive immunity are likely to be involved in IPF pathogenesis/ progression. Finally, the importance of the clotting cascade in IPF pathogenesis has been confirmed by a recent epidemiological study, in which patients with IPF were almost five times more likely than general population controls to have at least one inherited or acquired clotting defect.
\end{abstract}

\section{Introduction}

Idiopathic pulmonary fibrosis (IPF) is a progressive fibrotic disease limited to the lungs, occurring in older individuals, more frequently men, and characterized by a dismal prognosis, with a median survival of 3 to 5 years since diagnosis, although a wide variability in disease course is increasingly recognized. According to the more commonly held and current pathogenetic model, IPF results from recurrent injury to epithelial cells caused by a variety of exposures. These include cigarette smoke, dusts, and other environmental agents, which, in a genetically predisposed individual, lead to activation of abnormal pathways, resulting in failed resolution of the wound-healing response. This article does not aim to provide an exhaustive review of pathogenetic pathways in IPF, but rather will focus on selected topics, in particular on contributions to the understanding of IPF pathogenesis provided by recent genetic association studies, and other selected data and hypotheses.

\section{Genetic studies}

Genetic predisposition to IPF is supported by familial clustering, the occurrence of lung fibrosis in genetic multisystem disorders, and differing susceptibilities in humans exposed to similar levels of fibrogenic agents. Genetic association studies are useful in identifying relevant molecules/cell types among the wide array of potential pathogenetic pathways and can highlight otherwise unexpected areas. 


\section{The role of type II cells}

Mutations in the genes for surfactant protein C (SFTPC) and surfactant protein A2 (SFTPA2) have been described in association with familial lung fibrosis $[1,2]$ and rarely with sporadic IPF $[3,4]$. Although they account for only approximately $1 \%$ of familial cases, the fact that both surfactant proteins are exclusively synthesized by type II alveolar epithelial cells points to type II cell dysfunction as a key element in IPF. The relevance of type II cells is also suggested by the prognostic value of serum surfactant proteins in sporadic IPF and other interstitial lung diseases (ILDs) [5]. In addition to synthesizing surfactant proteins, type II alveolar cells are responsible for the constant regeneration of the alveolar epithelium, as precursors of the terminally differentiated type I cells. Surfactant protein $\mathrm{C}$ and A mutations have been shown to cause incorrect protein folding/processing, thereby activating the cell's endoplasmic reticulum (ER) stress response. This is a stereotypical protective mechanism in response to the accumulation of misfolded proteins, ultimately leading to activation of apoptosis pathways $[6,7]$. Increased staining for markers of ER stress response and apoptosis is also observed in sporadic IPF $[8,9]$, highlighting a prominent role for activation of the ER stress response and alveolar cell apoptosis in pathogenesis.

Type II cells are also affected in the Hermansky-Pudlak syndrome (HPS), a genetic disease frequently associated with lung fibrosis. HPS is caused by mutations in genes encoding for proteins involved in lysosome-related intracellular trafficking, leading to giant lamellar body formation in type II alveolar cells [10]. Although alveolar epithelial ER stress has been described in HPS lung fibrosis [11], Young and colleagues report that impaired intracellular trafficking pathways do not directly result in ER stress, suggesting further studies are needed to evaluate mechanisms [12].

\section{Telomere shortening}

Pulmonary fibrosis occurs in a subset of patients with dyskeratosis congenita, a rare genetic disorder. Rapidly dividing tissues are affected, including epithelial cells and bone marrow, secondary to mutations in genes encoding for telomerase enzyme components. Telomerases are responsible for the elongation of telomeres, repetitive DNA sequences capping chromosome ends. Telomeres shorten at each cell replication until a critical length is reached, triggering a DNA damage response, leading to cellular senescence or apoptosis. Loss of telomerase activity reduces the renewal potential of stem cell populations [13]. Rare mutations in the telomerase genes TERT and TERC have been identified in approximately $8 \%$ of familial cases and in $1 \%$ to $3 \%$ of sporadic cases $[14,15]$. Telomeres shorten with age, and telomere dysfunction may be involved in a number of age-related degenerative disorders [16]. Even in the absence of TERT/ TERC mutations, a proportion of IPF patients have shorter telomeres compared with age-matched controls $[17,18]$. In aggregate, these findings suggest that IPF may be a disease of accelerated aging in the lung, at least in the subset characterized by shortened telomeres. However, shorter telomeres in circulating leukocytes compared with age-matched control populations are also observed in chronic obstructive pulmonary disease (COPD), in asthma, and in association with lower lung function in control individuals, suggesting that the phenomenon of premature aging is not specific to pulmonary fibrosis [19].

The mechanisms through which telomere/telomerase defects may lead to pulmonary fibrosis are not well known. As telomerase dysfunction is most likely to affect cells with high turnover, epithelial cells are obvious candidates. Indeed, IPF alveolar epithelium had shorter telomeres than normal control epithelium, independently of detectable telomerase mutations in one study [17], although further studies are needed to confirm this interesting observation. Telomerase activity may differ according to cell type as increased telomerase activity has been reported in IPF lung fibroblasts, which is in keeping with potential increased survival and resistance to apoptosis in these cells [20].

\section{Bronchiolar cells}

A prominent role for activated bronchiolar-type epithelial cells was first proposed by Chilosi and colleagues, in a study reporting activation of the Wnt/beta-catenin/matrylisin developmental pathway in hyperplastic bronchiolar lesions [21]. This was a feature seen in IPF but not in other ILD patterns, in contrast with nuclear beta-catenin expression observed in type II pneumocytes across ILDs. A particularly strong beta-catenin staining in areas of bronchiolization was confirmed by Konigshoff and colleagues [22].

In genetic studies, a role for bronchiolar cells has been suggested by the finding of a marked increase in a MUC5B gene common promoter polymorphism in familial interstitial pneumonia (FIP) and sporadic IPF compared with controls (minor allele present in $33.8 \%$ of FIP cases, $37.5 \%$ of sporadic IPF cases, and $9.1 \%$ of control subjects) $[23,24]$. This strong association suggests the pathogenetic significance of mucins/small airways in IPF. By contrast, no association was found between MUC5B and scleroderma-associated lung fibrosis or with fibrotic sarcoidosis, suggesting that this association may be specific to the idiopathic ILDs $[25,26]$.

Although the MUC5B variants are associated with overexpression in lung tissue compared with non-carriers 
in control subjects, this is not the case in IPF, where lung MUC5B overexpression is seen independently of genetic variants [23]. This observation suggests that, in the absence of (or in addition to) MUC5B genetic variation, other environmental or genetic factors (or both) linked to disease pathogenesis cause its upregulation. MUC5B appears to localize mainly to the distal airways and to the honeycomb cysts in what appear to be bronchiolar cells rather than type II alveolar cells [27]. Honeycombing lesions would therefore derive from the dilatation of the small airways, an observation that was originally made more than 50 years ago [28]. The mucin-producing cells in the honeycombed areas are characterized by a transcription factor and mucin profile suggestive of abnormal programming, with a phenotype similar to that of submucosal gland goblet cells, normally not found in the distal airspaces [29]. The mechanism by which MUC5B polymorphisms predispose individuals to pulmonary fibrosis is not known. One of the hypotheses is that MUC5B variants may lead to impaired clearance of inhaled micro-organisms and other particles and therefore an aberrant innate response, although a direct toxic effect on epithelial cells and/or ectopic expression with intracellular accumulation and resulting ER stress response are also possibilities $[23,30]$.

Interestingly, while MUC5B overexpression is associated with IPF independently of the genetic polymorphisms, the MUC5B genetic variant actually appears to be associated with slower progression and better survival $[26,31]$, suggesting that it marks a subset of the disease. There is a known variability in the clinical course of IPF, ranging from prolonged stability/gradual worsening to rapid stepwise progression [32-34]. Disease subsets are also suggested by a recent whole-genome expression analysis in a large number of IPF biopsies [35]. Clustering of the genes differentially expressed compared with controls reveals a separation into two clear IPF subpopulations, based on a distinct molecular signature. One IPF group is characterized by overexpression (compared with the other) of a number of genes already known to be upregulated in IPF, including osteopontin, matrix metalloprotease 1 (MMP1), MMP7, and MUC5B. The same IPF group is also characterized by upregulation of a large number of transcripts associated with cilium genes. These include structural components such as axonemal dyneins involved in ciliary motility as well as transcription factors regulating cilium gene expression, including RFX3, FOXJ1, and RFX2. Patients with high cilium gene expression demonstrate more microscopic honeycombing but not more fibroblastic foci on lung biopsy [35]. These observations reinforce the role played by airway cells (at least in a subset) and for the first time provide molecular evidence that IPF may in fact consist of more than one disease, each with likely different pathogenesis, prognosis, and treatment responses. The authors do not mention whether these two subsets separate out according to the MUC5B polymorphisms or whether they are characterized by different longitudinal behavior, and no doubt further studies will shed light on this.

Two recent large genome-wide case-control association studies have confirmed the association with MUC5B $[36,37]$, with the study by Fingerlin and colleagues [36] also identifying associations with common variants in the TERT and TERC genes. Both studies also report associations with several novel common gene variants. Among these, Fingerlin and colleagues report an association with genes involved in epithelial integrity and cell-cell adhesion, including desmoplakin (DSP) and DPP9, suggesting that defects in cell-cell adhesion or cellular cytoskeleton (or both) could predispose patients to injury in response to stimuli, including mechanical stretch. Both studies report an association with TOLLIP, a regulator of innate immune responses involved in modulating Toll-like receptor (TLR) signaling. The TOLLIP gene resides close to $M U C 5 B$, and variants in the two genes are in weak linkage disequilibrium. Once the MUC5B variants were included in the analysis, the association with the TOLLIP gene single-nucleotide polymorphisms (SNPs) only just reached statistical significance in the study by Noth and colleagues [37] $(P=0.05)$ and was no longer significant in the study by Fingerlin and colleagues, indicating the need for further studies. Interestingly, the minor allele of one of the TOLLIP SNPs (rs5743890) found to be protective toward lung fibrosis was associated with worse survival. This finding was maintained on adjusting for other gene variants, although MUC5B was not included in the multivariate analysis [37]. Again, whether the TOLLIP variant is a prognostic determinant, independently of MUC5B, remains to be determined.

\section{Gene expression and epigenetic regulation}

Transcriptional profiling studies of fibrotic lung tissues have identified key differences with control tissues and between different fibrotic ILD patterns [38-41]. Matrilysin (MMP7), one of the downstream targets of Wnt/betacatenin, is highly overexpressed in IPF biopsies [38] and has been investigated as a peripheral blood biomarker in ILD. In the largest prospective biomarker study performed so far in IPF, MMP7, together with intercellular adhesion molecule-1 (ICAM-1) and interleukin-8 (IL-8), was the strongest predictor of survival in combination with clinical characteristics [42]. Boon and colleagues reported on upregulation in pathways involved in cell growth, proliferation, and migration in lung tissue from rapidly progressive compared with relatively stable IPF [43], suggesting that there may be common pathways 
between lung fibrosis and cancer development [44]. Rapidly progressive fibrosis was also characterized by upregulation of PLUNC, a molecule expressed mainly by secretory bronchial columnar cells, again highlighting a potential role for airway/innate defense functions [43]. With regard to fibroblasts, these are the main effector cell types involved in the fibrotic process [45], regardless of the initiating triggers. Gene expression profiling studies of cultured lung fibroblasts show specific pathways of activation [46-48], which appear to be similar in IPF and in scleroderma-associated ILD [48].

Although the study of epigenetic regulation in IPF is relatively recent, analysis in lung tissue or in IPF fibroblasts (or both) of the global and individual gene expression regulation through methylation [49-51], acetylation [52,53], and regulatory microRNAs [54-61] is providing information on regulatory networks and should allow a better understanding of how particular genetic variants and environmental exposures interact to cause pulmonary fibrosis, ultimately leading to novel treatment strategies.

\section{Innate and adaptive immune responses}

The role played by conventional inflammation in IPF pathogenesis has been questioned, mainly in view of the lack of response to corticosteroids and immunosuppressants, which may indeed be harmful in patients with IPF [62]. However, components of the innate and adaptive immune response are thought to contribute to the pathogenesis of lung fibrosis.

The innate immune system plays a crucial role in initiating and terminating inflammatory responses to endogenous and exogenous noxious stimuli. The alveolar macrophage is a potential source of chemokines and growth factors that regulate the wound-healing response. Macrophages are characterized by at least two phenotypes: $\mathrm{M} 1$, induced by Th1 cytokines such as interferon, and expressing IL-12, tumor necrosis factor (TNF), and C-X-C motif chemokine (CXCL)10, and M2 (or alternatively activated M), which expresses CD163, mannose receptors, and secretes increased levels of IL-10, chemokine (C-C motif) ligand (CCL) 18, and CCL22 [63]. Two carefully conducted large prospective studies have shown that bronchoalveolar lavage (BAL) and serum levels of CCL18, one of the markers of M2 macrophages, are significantly linked to extent of fibrosis and predict likelihood of progression, even after adjustment for disease severity, both in IPF and in systemic sclerosis-ILD [64,65].

Pattern recognition receptors, including TLRs, recognize pathogen and endogenous patterns, activate innate and adaptive immune responses, and participate in regulating wound healing [66]. Pathogen-associated molecular patterns (PAMPs) are suspected to play a role in the activation of fibroblasts through TLRs as well as nucleotide-binding oligomerization domain-like receptors (NLR)s and retinoic acid-inducible gene-1 (RIG-1) receptors [67]. Endogenous ligands can also be identified by TLRs, including components of the extracellular matrix such as hyaluronic acid [68], and fibrinogen degradation products [69]. Interestingly, the ligation of the latter to TLR4 has been shown to induce upregulation of mucin MUC5AC expression in both alveolar macrophages and epithelial cells [69].

TLR9 expression has been found to be increased in ILD lung tissue and in IPF fibroblasts compared with control subjects $[70,71]$. In particular, in both usual interstitial pneumonia (UIP) and non-specific interstitial pneumonia (NSIP), the increased expression is localized to areas of fibrosis in the epithelium and interstitium [70]. TLR9 activation by hypomethylated DNA significantly increased alpha smooth muscle actin [70] and promoted profibrotic cytokine and chemokine synthesis in IPF fibroblasts in culture [72]. TLR9 was particularly upregulated in the lung tissues of rapidly progressive IPF compared with more stable disease [73].

TLR3 has been shown to act as a sensor of tissue necrosis during acute inflammation. In addition, it recognizes virus-associated molecular patterns and activates proinflammatory cascades $[74,75]$. Recently, a TLR3 polymorphism (TLR3L412F) associated with defective function of the receptor was studied in patients with IPF. Fibroblasts homozygous for the variant allele had an impaired interferon-beta response, displaying enhanced proliferation after TLR3 stimulation, partially corrected after interferon-beta treatment. Furthermore, the variant was associated with disease progression or early mortality (or both) in two separate IPF cohorts, with an additive effect for each allele [76]. This study is another example of a genetic variant linked to outcome in IPF and highlights the possibility of differences in response to treatments in different subsets, as suggested by the editorial accompanying the article [77]. The activation of TLRs in epithelial and interstial cells could be one of the links between exogenous/endogenous noxious signals and amplification of immune and fibroproliferative responses. Further studies are needed to assess their role in the pathogenesis of pulmonary fibrosis.

Adaptive immunity is also likely to be involved in IPF progression. We know that in hypersensitivity pneumonitis (HP) adaptive immunity is a crucial driver of 
disease. A proportion of patients with fibrotic HP have a UIP histology and can display an IPF-like disease course [78], although features such as airway centeredness of fibrosis and excess inflammation suggest the diagnosis of HP-associated UIP [79]. There may be at least a subset of patients with IPF in whom the fibrotic response is a response to an unknown antigen, with a role played by adaptive immunity. Indeed, Gilani and colleagues found that increased proportions of circulating $\mathrm{CD} 28^{\text {null }} \mathrm{CD} 4^{+} \mathrm{T}$ cells are associated with poor outcomes in patients with IPF [80]. CD28 ${ }^{\text {null }} \mathrm{CD} 4^{+}$cells are effector memory $\mathrm{T}$ cells, which develop as a result of repeated antigen-driven proliferations. These cells display increased production of cytotoxic mediators and proinflammatory cytokines, in keeping with enhanced noxious potential. Interestingly, CD28 ${ }^{\text {null }} \mathrm{T}$-cell telomeres are shortened as a result of repetitive T-cell clonal proliferations [81], and T cells comprise $40 \%$ to $50 \%$ of peripheral blood monocytes. This could contribute to findings of telomere shortening in the peripheral blood leukocytes of IPF patients and other populations with chronic disease. The relevance of T-cell differentiation in IPF, again as a result of repetitive antigen stimulation, is also supported by a recent report by Herazo-Maya and colleagues [82]. BAL and lung tissue-activated $\mathrm{CD} 4^{+} \mathrm{T}$ cells are observed in asymptomatic early familial ILD cases [83], and pro-inflammatory dendritic cells are found in advanced lung fibrosis [84]. In IPF lungs, $\mathrm{CD}^{+}$ $\mathrm{T}$ lymphocytes correlated with degree of breathlessness and functional severity [85]. IPF lung-derived proteins induce proliferation of autologous CD4 T cells from these patients [86]. Semaphorin $7 \mathrm{a}^{+}$regulatory $\mathrm{T}$ cells are increased in the blood of patients with rapidly progressive IPF [87].

In addition to T cells, B cells may also be involved in IPF pathogenesis. Auto-antibodies against heat shock protein 70 (HSP 70) are associated with short-term deterioration in patients with IPF, independently of disease severity, suggesting a potential link to a pathogenetically significant process [88]. The finding of lymphoid follicles in IPF biopsies has been reported in a number of studies [89-91]. The presence of B-cell aggregates in injured tissues suggests a possible direct contribution of the significant pathogenetic potential of B cells to the fibrotic process [92]. Xue and colleagues observed an increase in circulating antigen-differentiated plasma cells in IPF patients and overexpression of a specific B-cell trophic factor (plasma B lymphocyte-stimulating factor), associated with poor short-term outcome [90]. A chemokine that mediates B-cell trafficking, CXCL13, was increased in the lung tissue and peripheral blood of IPF patients compared with healthy controls and COPD patients and was predictive of early mortality, further supporting a pathogenetic role for B cells [93].

It seems likely that both the innate and adaptive immune systems participate in lung fibrosis progression. However, the question of whether the hyperstimulation of the immune system described above is directly causative of lung fibrosis rather than a consequence of the loss of the normal lung architecture and therefore of natural defenses is more difficult to resolve. We should also consider the possibility of an interaction between the different pathogenetic mechanisms. For example, Agrawal and colleagues recently observed that an interaction between surfactant protein (SP)-A and TLR2 is involved in regulating secretion of pro-inflammatory mediators in macrophage lines both in vitro and in vivo [94].

\section{The clotting cascade}

The clotting cascade appears to be activated in pulmonary fibrosis, as suggested by in vitro and animal model studies [95]. Cleaved clotting factors have major pro-inflammatory and profibrogenic effects [96], and activated platelets/endothelial cells release fibrogenic mediators, including platelet-derived growth factor (PDGF) and transforming growth factor-beta (TGF $\beta$ ) [97]. Navaratnam and colleagues recently reported on a carefully conducted case-control study of 211 incident IPF cases to evaluate the incidence of clotting abnormalities identified through a pro-thrombotic panel of 11 clotting defects [98]. The authors found that patients with IPF have an almost fivefold greater chance of having at least one clotting abnormality, with incrementally increasing odds ratios for increasing numbers of clotting abnormalities. The highest odds ratios were seen for elevation of factor VIII levels $(>165 \mathrm{IU} / \mathrm{dL}$ in 124 out of 194 patients with IPF versus 45 out of 211 controls). Furthermore, clotting abnormalities were associated with more severe disease at baseline and a worse survival. How this fits with the recent trial of warfarin treatment in IPF, which was stopped early because of an increased rate of pulmonary fibrosis deterioration in the warfarin-treated arm [99], will need to be further investigated, but it does support previous studies pointing to an important role played by the coagulation system in the lung fibrosis process.

\section{Physical factors}

Leslie recently proposed a unifying hypothesis for IPF as a disease of "recurrent stretch injury to the peripheral and basal lung occurring over many years in predisposed individuals" [100]. This theory attempts to reconcile a number of unexplained features, including the predominantly basal and subpleural distribution, the progression 
of the disease toward the apical regions, and the finding that fibroblastic foci are a continuum extending inward from the pleural surface (fibroblastic reticulum) [101]. IPF would start in the basal and peripheral regions of the lungs, where the alveoli are the smallest in the upright and supine positions and are therefore more likely to collapse in response to the tractional forces during respiration, as also suggested by Galvin and colleagues [102] and Dail [103]. Surfactant protein abnormalities could lead to increased surface tension and greater likelihood of alveolar collapse, while the reticular network of fibroblastic foci would occur along stress fractures/lines at the interface between the epithelium and the mesenchymal cells. A vicious circle of increasing alveolar surface tension causing further alveolar collapse and subsequent enlargement of the alveolar ducts leading to microscopic honeycombing would follow. Carloni and colleagues applied a mathematical model to verify whether the distribution of IPF lesions corresponds to the areas of greatest mechanical tension [104]. If these mechanical forces have a role in the origin or in the progression of the disease, they should also influence those cases with associated emphysema, which were initially described more than 20 years ago [105] and which only recently have attracted the attention of researchers [106]. In these cases, one would expect a lower traction in the basal zones because of reduced elastic recoil of the upper parts of the lung.

\section{Conclusion}

In conclusion, genetic association studies suggest a pivotal pathogenetic role played by abnormal regeneration/ differentiation potential of respiratory epithelial cells in IPF (both alveolar and bronchiolar), which is likely to be determined by the interaction between environmental exposures such as cigarette smoke and gene variants, including surfactant protein and telomerase genes. The association with MUC5B suggests a role of airway epithelial cells and mucins. Further studies on how molecular phenotypes can be linked in to genetic data and to clinical, radiological, and histological characteristics of the disease will be crucial to predict clinical course and drive novel treatments in IPF.

\section{Abbreviations}

BAL, bronchoalveolar lavage; COPD, chronic obstructive pulmonary disease; CCL, chemokine (C-C motif) ligand; CXCL, C-X-C motif chemokine; ER, endoplasmic reticulum; FIP, familial interstitial pneumonia; HP, hypersensitivity pneumonitis; HPS, Hermansky-Pudlak syndrome; ILD, interstitial lung disease; IPF, idiopathic pulmonary fibrosis; MMP, matrix metalloprotease; SNP, singlenucleotide polymorphism; TLR, Toll-like receptor; UIP, usual interstitial pneumonia.

\section{Disclosures}

The authors declare that they have no disclosures.

\section{References}

I. Nogee LM, Dunbar AE, Wert SE, Askin F, Hamvas A, Whitsett JA: A mutation in the surfactant protein $C$ gene associated with familial interstitial lung disease. N Engl J Med 200I, 344:573-9.

FlOOOPrime

RECOMMENDED

2. Thomas AQ, Lane K, Phillips J, Prince M, Markin C, Speer M, Schwartz DA, Gaddipati R, Marney A, Johnson J, Roberts R, Haines J, Stahlman M, Loyd JE: Heterozygosity for a surfactant protein C gene mutation associated with usual interstitial pneumonitis and cellular nonspecific interstitial pneumonitis in one kindred. Am J Respir Crit Care Med 2002, 165:1322-8.

\section{FlOOOPrime \\ RECOMMENDED}

3. Markart P, Ruppert C, Wygrecka M, Schmidt R, Korfei M, Harbach H, Theruvath I, Pison U, Seeger W, Guenther A, Witt H: Surfactant protein C mutations in sporadic forms of idiopathic interstitial pneumonias. Eur Respir J 2007, 29:134-7.

\section{FlOOOPrime}

RECOMMENDED

4. Lawson WE, Grant SW, Ambrosini V, Womble KE, Dawson EP, Lane KB, Markin C, Renzoni E, Lympany P, Thomas AQ, Roldan J, Scott TA, Blackwell TS, Phillips JA, Loyd JE, du Bois, RM: Genetic mutations in surfactant protein $C$ are a rare cause of sporadic cases of IPF. Thorax 2004, 59:977-80.

5. Zhang Y, Kaminski N: Biomarkers in idiopathic pulmonary fibrosis. Curr Opin Pulm Med 20I2, 18:44I-6.

6. Kabore AF, Wang WJ, Russo SJ, Beers MF: Biosynthesis of surfactant protein $C$ : characterization of aggresome formation by EGFP chimeras containing propeptide mutants lacking conserved cysteine residues. J Cell Sci 200 I, I I 4:293-302.

7. Mulugeta S, Nguyen V, Russo SJ, Muniswamy M, Beers MF: A surfactant protein $C$ precursor protein BRICHOS domain mutation causes endoplasmic reticulum stress, proteasome dysfunction, and caspase 3 activation. Am J Respir Cell Mol Biol 2005, 32:52 I-30.

8. Lawson WE, Crossno PF, Polosukhin VV, Roldan J, Cheng D, Lane KB, Blackwell TR, Xu C, Markin C, Ware LB, Miller GG, Loyd JE, Blackwell TS: Endoplasmic reticulum stress in alveolar epithelial cells is prominent in IPF: association with altered surfactant protein processing and herpesvirus infection. Am J Physiol Lung Cell Mol Physiol 2008, 294:LI I I9-26.

9. Korfei M, Ruppert C, Mahavadi P, Henneke I, Markart P, Koch M, Lang G, Fink L, Bohle R, Seeger W, Weaver TE, Guenther A: Epithelial endoplasmic reticulum stress and apoptosis in sporadic idiopathic pulmonary fibrosis. Am J Respir Crit Care Med 2008, 178:838-46.

\section{FlOOOPrime}

\section{RECOMMENDED}

10. Nakatani $Y$, Nakamura N, Sano J, Inayama $Y$, Kawano N, Yamanaka S, Miyagi Y, Nagashima Y, Ohbayashi C, Mizushima M, Manabe T, Kuroda $M$, Yokoi $T$, Matsubara $O$ : Interstitial pneumonia in Hermansky-Pudlak syndrome: significance of florid foamy swelling/degeneration (giant lamellar body degeneration) of type-2 pneumocytes. Virchows Arch 2000, 437:304-13.

II. Mahavadi P, Korfei M, Henneke I, Liebisch G, Schmitz G, Gochuico BR, Markart P, Bellusci S, Seeger W, Ruppert C, Guenther A: Epithelial stress and apoptosis underlie Hermansky-Pudlak syndromeassociated interstitial pneumonia. Am J Respir Crit Care Med 2010, 182:207-19.

12. Young LR, Gulleman PM, Bridges JP, Weaver TE, Deutsch GH, Blackwell TS, McCormack FX: The alveolar epithelium determines susceptibility to lung fibrosis in Hermansky-Pudlak syndrome. Am J Respir Crit Care Med 2012, 186:1014-24.

FlOOOPrime RECOMMENDED 
13. Batista, Luis FZ, Pech MF, Zhong FL, Nguyen HN, Xie KT, Zaug AJ, Crary SM, Choi J, Sebastiano V, Cherry A, Giri N, Wernig M, Alter BP, Cech TR, Savage SA, Reijo Pera, Renee A, Artandi SE: Telomere shortening and loss of self-renewal in dyskeratosis congenita induced pluripotent stem cells. Nature 201 I, 474:399-402.

14. Armanios MY, Chen JJ, Cogan JD, Alder JK, Ingersoll RG, Markin C, Lawson WE, Xie M, Vulto I, Phillips JA, Lansdorp PM, Greider CW, Loyd JE: Telomerase mutations in families with idiopathic pulmonary fibrosis. $N$ Engl J Med 2007, 356:1317-26.

\section{FlOOOPrime}

RECOMMENDED

15. Tsakiri KD, Cronkhite JT, Kuan PJ, Xing C, Raghu G, Weissler JC, Rosenblatt RL, Shay JW, Garcia CK: Adult-onset pulmonary fibrosis caused by mutations in telomerase. Proc Natl Acad Sci USA 2007, 104:7552-7.

FlOOOPrime RECOMMENDED

16. Armanios M, Blackburn EH: The telomere syndromes. Nat Rev Genet 2012, 13:693-704.

17. Alder JK, Chen JJ, Lancaster L, Danoff S, Su S, Cogan JD, Vulto I, Xie M, Qi X, Tuder RM, Phillips JA, Lansdorp PM, Loyd JE, Armanios MY: Short telomeres are a risk factor for idiopathic pulmonary fibrosis. Proc Natl Acad Sci USA 2008, 105: I 305 I-6.

\section{FIOOOPrime}

RECOMMENDED

18. Cronkhite JT, Xing C, Raghu G, Chin KM, Torres F, Rosenblatt RL, Garcia CK: Telomere shortening in familial and sporadic pulmonary fibrosis. Am J Respir Crit Care Med 2008, 178:729-37.

\section{FIOOOPrime}

\section{RECOMMENDED}

19. Albrecht E, Sillanpää E, Karrasch S, Alves AC, Codd V, Hovatta I, Buxton JL, Nelson CP, Broer L, Hägg S, Mangino M, Willemsen G, Surakka I, Ferreira, Manuel AR, Amin N, Oostra BA, Bäckmand HM, Peltonen M, Sarna S, Rantanen T, Sipilä S, Korhonen T, Madden, Pamela AF, Gieger C, Jörres RA, Heinrich J, Behr J, Huber RM, Peters A, Strauch K, et al.: Telomere length in circulating leukocytes is associated with lung function and disease. Eur Respir J 20I4, 43:983-92.

20. Liu T, Ullenbruch M, Young Choi Y, Yu H, Ding L, Xaubet A, Pereda J, Feghali-Bostwick CA, Bitterman PB, Henke CA, Pardo A, Selman M, Phan SH: Telomerase and telomere length in pulmonary fibrosis. Am J Respir Cell Mol Biol 2013, 49:260-8.

\section{FlOOOPrime \\ RECOMMENDED}

21. Chilosi M, Poletti V, Zamò A, Lestani M, Montagna L, Piccoli P, Pedron S, Bertaso M, Scarpa A, Murer B, Cancellieri A, Maestro R, Semenzato G, Doglioni C: Aberrant Wnt/beta-catenin pathway activation in idiopathic pulmonary fibrosis. Am J Pathol 2003, 162:1495-502.

\section{FlOOOPrime}

\section{RECOMMENDED}

22. Königshoff M, Balsara N, Pfaff E, Kramer M, Chrobak I, Seeger W, Eickelberg O: Functional Wnt signaling is increased in idiopathic pulmonary fibrosis. PLOS ONE 2008, 3:e2I 42.

23. Seibold MA, Wise AL, Speer MC, Steele MP, Brown KK, Loyd JE, Fingerlin TE, Zhang W, Gudmundsson G, Groshong SD, Evans CM, Garantziotis S, Adler KB, Dickey BF, du Bois, Roland M, Yang IV, Herron A, Kervitsky D, Talbert JL, Markin C, Park J, Crews AL, Slifer SH, Auerbach S, Roy MG, Lin J, Hennessy CE, Schwarz MI, Schwartz DA: A common MUC5B promoter polymorphism and pulmonary fibrosis. N Engl J Med 20I I, 364:I 503-12.

\section{FlOOOPrime RECOMMENDED}

24. Zhang Y, Noth I, Garcia, Joe GN, Kaminski N: A variant in the promoter of MUC5B and idiopathic pulmonary fibrosis. $N$ Engl J Med 20I I, 364:I576-7.
25. Peljto AL, Steele MP, Fingerlin TE, Hinchcliff ME, Murphy E, Podlusky S, Carns M, Schwarz M, Varga J, Schwartz DA: The pulmonary fibrosis-associated MUC5B promoter polymorphism does not influence the development of interstitial pneumonia in systemic sclerosis. Chest 2012, 142:1584-8.

26. Stock CJ, Sato H, Fonseca C, Banya, Winston AS, Molyneaux PL, Adamali $H$, Russell A, Denton CP, Abraham DJ, Hansell DM, Nicholson AG, Maher TM, Wells AU, Lindahl GE, Renzoni EA: Mucin 5B promoter polymorphism is associated with idiopathic pulmonary fibrosis but not with development of lung fibrosis in systemic sclerosis or sarcoidosis. Thorax 2013, 68:436-4I.

27. Seibold MA, Smith RW, Urbanek C, Groshong SD, Cosgrove GP, Brown KK, Schwarz MI, Schwartz DA, Reynolds SD: The idiopathic pulmonary fibrosis honeycomb cyst contains a mucocilary pseudostratified epithelium. PLOS ONE 2013, 8:e58658.

28. Heppleston AG: The pathology of honeycomb lung. Thorax 1956, II:77-93.

29. Plantier L, Crestani B, Wert SE, Dehoux M, Zweytick B, Guenther A, Whitsett JA: Ectopic respiratory epithelial cell differentiation in bronchiolised distal airspaces in idiopathic pulmonary fibrosis. Thorax 2011, 66:651-7.

\section{FlOOOPrime}

RECOMMENDED

30. Boucher RC: Idiopathic pulmonary fibrosis-a sticky business. N Engl J Med 20I I, 364:I560-I.

31. Peljto AL, Zhang Y, Fingerlin TE, Ma S, Garcia, Joe GN, Richards TJ, Silveira LJ, Lindell KO, Steele MP, Loyd JE, Gibson KF, Seibold MA, Brown KK, Talbert JL, Markin C, Kossen K, Seiwert SD, Murphy E, Noth I, Schwarz MI, Kaminski N, Schwartz DA: Association between the MUC5B promoter polymorphism and survival in patients with idiopathic pulmonary fibrosis. JAMA 2013, 309:2232-9.

\section{FIOOOPrime}

32. Ley B, Collard HR, King TE: Clinical course and prediction of survival in idiopathic pulmonary fibrosis. Am J Respir Crit Care Med 20II, I 83:43I-40.

33. Kim DS, Collard HR, King TE: Classification and natural history of the idiopathic interstitial pneumonias. Proc Am Thorac Soc 2006, 3:285-92.

34. Selman M, Carrillo G, Estrada A, Mejia M, Becerril C, Cisneros J, Gaxiola M, Pérez-Padilla R, Navarro C, Richards T, Dauber J, King TE, Pardo A, Kaminski N: Accelerated variant of idiopathic pulmonary fibrosis: clinical behavior and gene expression pattern. PLOS ONE 2007, 2:e482.

35. Yang IV, Coldren CD, Leach SM, Seibold MA, Murphy E, Lin J, Rosen R, Neidermyer AJ, McKean DF, Groshong SD, Cool C, Cosgrove GP, Lynch DA, Brown KK, Schwarz MI, Fingerlin TE, Schwartz DA: Expression of cilium-associated genes defines novel molecular subtypes of idiopathic pulmonary fibrosis. Thorax 2013, 68: I||4-2|.

\section{FlOOOPrime \\ RECOMMENDED}

36. Fingerlin TE, Murphy E, Zhang W, Peljto AL, Brown KK, Steele MP, Loyd JE, Cosgrove GP, Lynch D, Groshong S, Collard HR, Wolters PJ, Bradford WZ, Kossen K, Seiwert SD, du Bois, Roland M, Garcia CK, Devine MS, Gudmundsson G, Isaksson HJ, Kaminski N, Zhang Y, Gibson KF, Lancaster LH, Cogan JD, Mason WR, Maher TM, Molyneaux PL, Wells AU, Moffatt MF, et al.: Genome-wide association study identifies multiple susceptibility loci for pulmonary fibrosis. Nat Genet 2013, 45:613-20.

\section{FlOOOPrime
RECOMMENDED}

37. Noth I, Zhang Y, Ma S, Flores C, Barber M, Huang Y, Broderick SM, Wade MS, Hysi P, Scuirba J, Richards TJ, Juan-Guardela BM, Vij R, Han MK, Martinez FJ, Kossen K, Seiwert SD, Christie JD, Nicolae D, Kaminski N, Garcia, Joe GN: Genetic variants associated with idiopathic pulmonary fibrosis susceptibility 
and mortality: a genome-wide association study. Lancet Respir Med 2013, 1:309-17.

\section{FIOOOPrime}

38. Zuo F, Kaminski N, Eugui E, Allard J, Yakhini Z, Ben-Dor A, Lollini L, Morris D, Kim Y, DeLustro B, Sheppard D, Pardo A, Selman M, Heller RA: Gene expression analysis reveals matrilysin as a key regulator of pulmonary fibrosis in mice and humans. Proc Natl Acad Sci USA 2002, 99:6292-7.

39. Mura M, Anraku M, Yun Z, McRae K, Liu M, Waddell TK, Singer LG, Granton JT, Keshavjee S, Perrot $M$ de: Gene expression profiling in the lungs of patients with pulmonary hypertension associated with pulmonary fibrosis. Chest 20I2, I4I:66 I-73.

\section{FlOOOPrime \\ RECOMMENDED}

40. Selman M, Pardo A, Barrera L, Estrada A, Watson SR, Wilson K, Aziz N, Kaminski N, Zlotnik A: Gene expression profiles distinguish idiopathic pulmonary fibrosis from hypersensitivity pneumonitis. Am J Respir Crit Care Med 2006, I 73: I 88-98.

\section{FlOOOPrime \\ RECOMMENDED}

41. Hsu E, Shi H, Jordan RM, Lyons-Weiler J, Pilewski JM, FeghaliBostwick CA: Lung tissues in patients with systemic sclerosis have gene expression patterns unique to pulmonary fibrosis and pulmonary hypertension. Arthritis Rheum 201 I, 63:783-94.

42. Richards TJ, Kaminski N, Baribaud F, Flavin S, Brodmerkel C, Horowitz D, Li K, Choi J, Vuga LJ, Lindell KO, Klesen M, Zhang Y, Gibson KF: Peripheral blood proteins predict mortality in idiopathic pulmonary fibrosis. Am J Respir Crit Care Med 2012, I 85:67-76.

\section{FlOOOPrime

RECOMMENDED

43. Boon K, Bailey NW, Yang J, Steel MP, Groshong S, Kervitsky D, Brown KK, Schwarz MI, Schwartz DA: Molecular phenotypes distinguish patients with relatively stable from progressive idiopathic pulmonary fibrosis (IPF). PLoS ONE 2009, 4:e5I34.

\section{FlOOOPrime}

RECOMMENDED

44. Vancheri C: Common pathways in idiopathic pulmonary fibrosis and cancer. Eur Respir Rev 2013, 22:265-72.

45. McAnulty RJ: Fibroblasts and myofibroblasts: their source, function and role in disease. Int J Biochem Cell Biol 2007, 39:666-7I.

46. Emblom-Callahan MC, Chhina MK, Shlobin OA, Ahmad S, Reese ES, lyer, Eswar PR, Cox DN, Brenner R, Burton NA, Grant GM, Nathan SD: Genomic phenotype of non-cultured pulmonary fibroblasts in idiopathic pulmonary fibrosis. Genomics 2010, 96:134-45.

47. Bridges RS, Kass D, Loh K, Glackin C, Borczuk AC, Greenberg S: Gene expression profiling of pulmonary fibrosis identifies Twist I as an antiapoptotic molecular "rectifier" of growth factor signaling. Am J Pathol 2009, I75:235I-6I.

48. Lindahl GE, Stock C], Shi-Wen X, Leoni P, Sestini P, Howat SL, BouGharios G, Nicholson AG, Denton CP, Grutters JC, Maher TM, Wells AU, Abraham DJ, Renzoni EA: Microarray profiling reveals suppressed interferon stimulated gene program in fibroblasts from scleroderma-associated interstitial lung disease. Respir Res 2013, 14:80.

49. Sanders YY, Ambalavanan N, Halloran B, Zhang X, Liu H, Crossman DK, Bray M, Zhang K, Thannickal VJ, Hagood JS: Altered DNA methylation profile in idiopathic pulmonary fibrosis. Am J Respir Crit Care Med 2012, 186:525-35.

\section{FIOOOPrime}

\section{RECOMMENDED}

50. Rabinovich El, Kapetanaki MG, Steinfeld I, Gibson KF, Pandit KV, Yu G, Yakhini Z, Kaminski N: Global methylation patterns in idiopathic pulmonary fibrosis. PLoS ONE 2012, 7:e33770.
5I. Huang SK, Fisher AS, Scruggs AM, White ES, Hogaboam CM, Richardson BC, Peters-Golden M: Hypermethylation of PTGER2 confers prostaglandin E2 resistance in fibrotic fibroblasts from humans and mice. Am J Pathol 2010, 177:2245-55.

52. Sanders YY, Tollefsbol TO, Varisco BM, Hagood JS: Epigenetic regulation of thy- $I$ by histone deacetylase inhibitor in rat lung fibroblasts. Am J Respir Cell Mol Biol 20I I, 45:I6-23.

53. Coward WR, Watts K, Feghali-Bostwick CA, Jenkins G, Pang L: Repression of IP-IO by interactions between histone deacetylation and hypermethylation in idiopathic pulmonary fibrosis. Mol Cell Biol 2010, 30:2874-86.

54. Oak SR, Murray L, Herath A, Sleeman M, Anderson I, Joshi AD, Coelho AL Flaherty KR, Toews GB, Knight D, Martinez FJ, Hogaboam CM: A micro RNA processing defect in rapidly progressing idiopathic pulmonary fibrosis. PLoS ONE 20II, 6:e2I 253.

\section{FlOOOPrime}

\section{RECOMMENDED}

55. Yamada M, Kubo H, Ota C, Takahashi T, Tando Y, Suzuki T, Fujino N, Makiguchi T, Takagi K, Suzuki T, Ichinose $M$ : The increase of microRNA-2I during lung fibrosis and its contribution to epithelial-mesenchymal transition in pulmonary epithelial cells. Respir Res 2013, I4:95.

56. Lino Cardenas, Christian Lacks, Henaoui IS, Courcot E, Roderburg C, Cauffiez C, Aubert S, Copin M, Wallaert B, Glowacki F, Dewaeles E, Milosevic J, Maurizio J, Tedrow J, Marcet B, Lo-Guidice J, Kaminski N, Barbry P, Luedde T, Perrais M, Mari B, Pottier N: miR-199a-5p Is upregulated during fibrogenic response to tissue injury and mediates TGFbeta-induced lung fibroblast activation by targeting caveolin-I. PLoS Genet 20I3, 9:el00329I.

57. Yang S, Cui H, Xie N, Icyuz M, Banerjee S, Antony VB, Abraham E, Thannickal V], Liu G: miR-I45 regulates myofibroblast differentiation and lung fibrosis. FASEB J 20I3, 27:2382-9I.

58. Pandit KV, Corcoran D, Yousef H, Yarlagadda M, Tzouvelekis A, Gibson KF, Konishi K, Yousem SA, Singh M, Handley D, Richards T, Selman M, Watkins SC, Pardo A, Ben-Yehudah A, Bouros D, Eickelberg $\mathrm{O}$, Ray $\mathrm{P}$, Benos PV, Kaminski N: Inhibition and role of let-7d in idiopathic pulmonary fibrosis. Am J Respir Crit Care Med 2010, 182:220-9.

59. Dakhlallah D, Batte K, Wang Y, Cantemir-Stone CZ, Yan P, Nuovo G Mikhail A, Hitchcock CL, Wright VP, Nana-Sinkam SP, Piper MG, Marsh $C B$ : Epigenetic regulation of miR-I7 92 contributes to the pathogenesis of pulmonary fibrosis. Am J Respir Crit Care Med 2013, I 87:397-405.

60. Pandit KV, Milosevic J, Kaminski $\mathrm{N}$ : MicroRNAs in idiopathic pulmonary fibrosis. Transl Res 20II, I57:191-9.

61. Hogaboam CM, Murray L, Martinez FJ: Epigenetic mechanisms through which Toll-like receptor-9 drives idiopathic pulmonary fibrosis progression. Proc Am Thorac Soc 2012, 9:172-6.

62. Raghu G, Anstrom KJ, King TE, Lasky JA, Martinez FJ: Prednisone, azathioprine, and $\mathrm{N}$-acetylcysteine for pulmonary fibrosis. N Engl J Med 2012, 366:1968-77.

\section{FlOOOPRIME
RECOMMENDED}

63. Mantovani A, Sozzani S, Locati M, Allavena P, Sica A: Macrophage polarization: tumor-associated macrophages as a paradigm for polarized M2 mononuclear phagocytes. Trends Immunol 2002, 23:549-55.

64. Prasse A, Probst C, Bargagli E, Zissel G, Toews GB, Flaherty KR, Olschewski M, Rottoli P, Müller-Quernheim J: Serum CC-chemokine ligand 18 concentration predicts outcome in idiopathic pulmonary fibrosis. Am J Respir Crit Care Med 2009, I 79:7| 7-23.

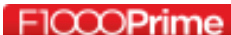

RECOMMENDED

65. Tiev KP, Hua-Huy T, Kettaneh A, Gain M, Duong-Quy S, Tolédano C, Cabane J, Dinh-Xuan AT: Serum CC chemokine ligand-18 
predicts lung disease worsening in systemic sclerosis. Eur Respir J 2011, 38:1355-60.

\section{FIOOOPrime}

66. Huebener P, Schwabe RF: Regulation of wound healing and organ fibrosis by toll-like receptors. Biochim Biophys Acta 2013, I 832:1005- 17.

67. Kawai T, Akira S: The roles of TLRs, RLRs and NLRs in pathogen recognition. Int Immunol 2009, 2 I:3 I7-37.

68. Scheibner KA, Lutz MA, Boodoo S, Fenton MJ, Powell JD, Horton MR: Hyaluronan fragments act as an endogenous danger signal by engaging TLR2. J Immunol 2006, I 77:|272-8I.

69. Millien VO, Lu W, Shaw J, Yuan X, Mak G, Roberts L, Song L, Knight JM, Creighton Cl, Luong A, Kheradmand F, Corry DB: Cleavage of fibrinogen by proteinases elicits allergic responses through Toll-like receptor 4. Science 20 I3, 34 I:792-6.

\section{FlOOOPrime}

\section{RECOMMENDED}

70. Meneghin A, Choi ES, Evanoff HL, Kunkel SL, Martinez FJ, Flaherty KR, Toews GB, Hogaboam CM: TLR9 is expressed in idiopathic interstitial pneumonia and its activation promotes in vitro myofibroblast differentiation. Histochem Cell Biol 2008, 130:979-92

\section{FIOOOPrime
RECOMMENDED}

7I. Margaritopoulos GA, Antoniou KM, Karagiannis K, Samara KD, Lasithiotaki I, Vassalou E, Lymbouridou R, Koutala H, Siafakas NM: Investigation of Toll-like receptors in the pathogenesis of fibrotic and granulomatous disorders: a bronchoalveolar lavage study. Fibrogenesis Tissue Repair 2010, 3:20.

\section{FIOOOPrime}

72. Hogaboam CM, Trujillo G, Martinez FJ: Aberrant innate immune sensing leads to the rapid progression of idiopathic pulmonary fibrosis. Fibrogenesis Tissue Repair 2012, 5(Suppl I):S3.

\section{FlOOOPrime
RECOMMENDED}

73. Trujillo G, Meneghin A, Flaherty KR, Sholl LM, Myers JL, Kazerooni EA, Gross BH, Oak SR, Coelho AL, Evanoff H, Day E, Toews GB, Joshi AD, Schaller MA, Waters B, Jarai G, Westwick J, Kunkel SL, Martinez FJ, Hogaboam CM: TLR9 differentiates rapidly from slowly progressing forms of idiopathic pulmonary fibrosis. Sci Transl Med 2010, 2:57ra82.

\section{FIOOOPrime}

74. Cavassani KA, Ishii M, Wen H, Schaller MA, Lincoln PM, Lukacs NW, Hogaboam CM, Kunkel SL: TLR3 is an endogenous sensor of tissue necrosis during acute inflammatory events. J Exp Med 2008, 205:2609-2I.

\section{FlOOPPrime}

\section{RECOMMENDED}

75. Kawai T, Akira S: The role of pattern-recognition receptors in innate immunity: update on Toll-like receptors. Nat Immunol 2010, I I:373-84

76. O'Dwyer DN, Armstrong ME, Trujillo G, Cooke G, Keane MP, Fallon PG, Simpson AJ, Millar AB, McGrath EE, Whyte MK, Hirani N, Hogaboam CM, Donnelly SC: The Toll-like receptor 3 L4I2F polymorphism and disease progression in idiopathic pulmonary fibrosis. Am J Respir Crit Care Med 2013, I 88: |442-50.

\section{FlOOOPrime
RECOMMENDED}

77. Noth I, Kaminski N: Idiopathic pulmonary fibrosis: time to get personal? Am J Respir Crit Care Med 2013, I 88: I 392-4.

78. Fink JN, Ortega HG, Reynolds HY, Cormier YF, Fan LL, Franks T], Kreiss K, Kunkel S, Lynch D, Quirce S, Rose C, Schleimer RP, Schuyler MR, Selman M, Trout D, Yoshizawa Y: Needs and opportunities for research in hypersensitivity pneumonitis. Am J Respir Crit Care Med 2005, I 71:792-8.

79. Takemura T, Akashi T, Kamiya H, Ikushima S, Ando T, Oritsu M, Sawahata M, Ogura T: Pathological differentiation of chronic hypersensitivity pneumonitis from idiopathic pulmonary fibrosis/usual interstitial pneumonia. Histopathology 2012, 6l:1026-35.

80. Gilani SR, Vuga LJ, Lindell KO, Gibson KF, Xue J, Kaminski N Valentine VG, Lindsay EK, George MP, Steele C, Duncan SR: CD28 down-regulation on circulating CD4 T-cells is associated with poor prognoses of patients with idiopathic pulmonary fibrosis. PLOS ONE 2010, 5:e8959.

\section{FlOOOPrime
RECOMMENDED}

8I. Moro-García MA, Alonso-Arias R, López-Larrea C: Molecular mechanisms involved in the aging of the $\mathrm{T}$-cell immune response. Curr Genomics 2012, 13:589-602.

82. Herazo-Maya JD, Noth I, Duncan SR, Kim S, Ma S, Tseng GC Feingold E, Juan-Guardela BM, Richards TJ, Lussier Y, Huang Y, Vij R, Lindell KO, Xue J, Gibson KF, Shapiro SD, Garcia, Joe GN, Kaminski N: Peripheral blood mononuclear cell gene expression profiles predict poor outcome in idiopathic pulmonary fibrosis. Sci Transl Med 2013, 5:205ral 36.

\section{FlOOOPrime}

RECOMMENDED

83. Rosas IO, Ren $\mathrm{P}$, Avila NA, Chow CK, Franks TJ, Travis WD, McCoy JP, May RM, Wu H, Nguyen DM, Arcos-Burgos M, MacDonald SD, Gochuico BR: Early interstitial lung disease in familial pulmonary fibrosis. Am J Respir Crit Care Med 2007 I 76:698-705

\section{FlOOOPrime}

84. Marchal-Sommé J, Uzunhan Y, Marchand-Adam S, Kambouchner M, Valeyre D, Crestani B, Soler P: Dendritic cells accumulate in human fibrotic interstitial lung disease. Am J Respir Crit Care Med 2007, I76:1007-14.

85. Daniil Z, Kitsanta P, Kapotsis G, Mathioudaki M, Kollintza A, Karatza M, Milic-Emili J, Roussos C, Papiris SA: CD8+ T lymphocytes in lung tissue from patients with idiopathic pulmonary fibrosis. Respir Res 2005, 6:81.

86. Feghali-Bostwick CA, Tsai CG, Valentine VG, Kantrow S, Stoner MW Pilewski JM, Gadgil A, George MP, Gibson KF, Choi, Augustine MK, Kaminski N, Zhang Y, Duncan SR: Cellular and humoral autoreactivity in idiopathic pulmonary fibrosis. I Immunol 2007, 179:2592-9.

FlOOOPrime

87. Reilkoff RA, Peng H, Murray LA, Peng $X$, Russell T, Montgomery R, Feghali-Bostwick C, Shaw A, Homer RJ, Gulati M, Mathur A, Elias JA Herzog EL: Semaphorin $\mathbf{7 a}+$ regulatory $T$ cells are associated with progressive idiopathic pulmonary fibrosis and are implicated in transforming growth factor- $\beta \mid$-induced pulmonary fibrosis. Am J Respir Crit Care Med 2013, I87:180-8.

\section{FlOOOPrime}

\section{RECOMMENDED}

88. Kahloon RA, Xue J, Bhargava A, Csizmadia E, Otterbein L, Kass DJ, Bon J, Soejima M, Levesque MC, Lindell KO, Gibson KF, Kaminski N Banga G, Oddis CV, Pilewski JM, Sciurba FC, Donahoe M, Zhang Y, Duncan SR: Patients with idiopathic pulmonary fibrosis with antibodies to heat shock protein $\mathbf{7 0}$ have poor prognoses. Am J Respir Crit Care Med 2013, I87:768-75.

\section{FlOOOPrime}

RECOMMENDED

89. Marchal-Sommé J, Uzunhan Y, Marchand-Adam S, Valeyre D, Soumelis V, Crestani B, Soler P: Cutting edge: nonproliferating mature immune cells form a novel type of organized lymphoid 
structure in idiopathic pulmonary fibrosis. J Immunol 2006, I76:5735-9.

\section{FlOOOPrime}

90. Xue J, Kass DJ, Bon J, Vuga L, Tan J, Csizmadia E, Otterbein L, Soejima M, Levesque MC, Gibson KF, Kaminski N, Pilewski JM, Donahoe M, Sciurba FC, Duncan SR: Plasma B lymphocyte stimulator and $B$ cell differentiation in idiopathic pulmonary fibrosis patients. J Immunol 2013, 191:2089-95.

\section{FlOOOPRime
RECOMMENDED}

91. Campbell DA, Poulter LW, Janossy G, du Bois, RM: Immunohistological analysis of lung tissue from patients with cryptogenic fibrosing alveolitis suggesting local expression of immune hypersensitivity. Thorax 1985, 40:405-II.

92. Browning JL: B cells move to centre stage: novel opportunities for autoimmune disease treatment. Nat Rev Drug Discov 2006, 5:564-76.

93. Vuga LJ, Tedrow JR, Pandit KV, Tan J, Kass DJ, Xue J, Chandra D, Leader JK, Gibson KF, Kaminski N, Sciurba FC, Duncan SR: C-X-C Motif Chemokine 13 (CXCLI3) Is a Prognostic Biomarker of Idiopathic Pulmonary Fibrosis. Am J Respir Crit Care Med 2014, I89:966-74.

\section{FlOOOPrime}

\section{RECOMMENDED}

94. Agrawal V, Smart K, jilling T, Hirsch E: Surfactant protein (SP)-A suppresses preterm delivery and inflammation via TLR2. PLOS ONE 2013, 8:e63990.

95. Chambers RC: Abnormal wound healing responses in pulmonary fibrosis: focus on coagulation signalling. Eur Respir Rev 2008, 17:130-7.

96. Scotton CJ, Krupiczojc MA, Königshoff M, Mercer PF, Lee, YC Gary, Kaminski N, Morser J, Post JM, Maher TM, Nicholson AG, Moffatt JD, Laurent G], Derian CK, Eickelberg O, Chambers RC: Increased local expression of coagulation factor $X$ contributes to the fibrotic response in human and murine lung injury. I Clin Invest 2009, II 19:2550-63.

\section{FlOOOPrime}

97. Steinhubl SR: Platelets as mediators of inflammation. Hematol Oncol Clin North Am 2007, 21:II5-2I.
98. Navaratnam V, Fogarty AW, McKeever T, Thompson N, Jenkins G, Johnson SR, Dolan G, Kumaran M, Pointon K, Hubbard RB: Presence of a prothrombotic state in people with idiopathic pulmonary fibrosis: a population-based case-control study. Thorax 2014, 69:207-15.

\section{FlOOOPrime}

RECOMMENDED

99. Noth I, Anstrom KJ, Calvert SB, Andrade J de, Flaherty KR, Glazer C Kaner RJ, Olman MA: A placebo-controlled randomized trial of warfarin in idiopathic pulmonary fibrosis. Am J Respir Crit Care Med 20I2, 186:88-95.

FlOOOPrime RECOMMENDED

100. Leslie KO: Idiopathic pulmonary fibrosis may be a disease of recurrent, tractional injury to the periphery of the aging lung: a unifying hypothesis regarding etiology and pathogenesis. Arch Pathol Lab Med 2012, I36:59|-600.

\section{FlOOOPrime}

10I. Cool CD, Groshong SD, Rai PR, Henson PM, Stewart JS, Brown KK: Fibroblast foci are not discrete sites of lung injury or repair: the fibroblast reticulum. Am J Respir Crit Care Med 2006, 174:654-8.

\section{FlOOOPrime} RECOMMENDED

102. Galvin JR, Frazier AA, Franks TJ: Collaborative radiologic and histopathologic assessment of fibrotic lung disease. Radiology 2010, 255:692-706.

103. Dail DH: Pulmonary apical cap. Am J Surg Pathol 200I, 25:I344.

104. Carloni A, Poletti V, Fermo L, Bellomo N, Chilosi M: Heterogeneous distribution of mechanical stress in human lung: a mathematical approach to evaluate abnormal remodeling in IPF. J Theor Biol 2013, 332:136-40.

\section{FlOOOPrime}

\section{RECOMMENDED}

105. Wiggins J, Strickland B, Turner-Warwick M: Combined cryptogenic fibrosing alveolitis and emphysema: the value of high resolution computed tomography in assessment. Respir Med 1990, 84:365-9.

106. Cottin V, Cordier J: The syndrome of combined pulmonary fibrosis and emphysema. Chest 2009, 136:I-2. 